\title{
Gambaran Pola Dermatoglifi pada Ujung Jari Tangan Penderita Penyakit Hipertensi Esensial di Kota Padang Tahun 2014
}

\author{
Ando Amadino ${ }^{1}$, Rika Susanti ${ }^{2}$, Rudi Afriant ${ }^{3}$
}

\begin{abstract}
Abstrak
Faktor genetik telah dibuktikan di dalam berbagai penelitian, merupakan penyebab penyakit hipertensi esensial dan diyakini dengan melihat dermatoglifinya dapat diperkirakan kemungkinan seseorang terkena penyakit ini. Beberapa penelitian telah mendapatkan hasil signifikan untuk pola loop dan whorl sebagai pola penanda kemungkinan hipertensi esensial. Tujuan penelitian ini adalah untuk mengetahui gambaran pola dermatoglifi pada penderita hipertensi esensial. Penelitian ini menggunakan desain deskriptif terhadap 100 orang. Pengumpulan data dilakukan dengan mengoleskan tinta berwarna gelap pada ujung jari tangan dan dicetakkan di atas kertas dengan cara digulingkan. Subjek penelitian ini telah didiagnosis hipertensi esensial oleh dokter. Hasil penelitian didapatkan bahwa penderita hipertensi esensial terbanyak pada kelompok umur 51-60 tahun. Frekuensi pola tertinggi adalah pola loop $(50,2 \%)$. Frekuensi tertinggi total sulur rata-rata terdapat lebih dari 20 sulur $(31 \%)$. Jumlah triradius normal dan berfungsi sebagai patokan dalam menghitung jumlah sulur. Penelitian ini memperlihatkan bahwa frekuensi tertinggi didapat adalah pola loop, tingginya jumlah sulur rata-rata dan jumlah triradius normal pada penderita hipertensi esensial.
\end{abstract}

Kata Kunci: hipertensi esensial, dermatoglifi

\section{Abstract}

Various studies have shown that there are some genetic factors which are involved in the causation of essential hypertension and its possible to certain extent to predict from dermatoglyphics individual's chance of acquiring essential hypertension. There are some significant result for whorl and loop pattern in other study of dermatoglyphics relationship wih essential hypertension. The objective of this study was to know the fingertip dermatoglyphics presentation in patient with essential hypertension. This study used a descriptive design on 100 subjects. Data were collected by smear dark ink to the fingertips and print it to the paper one by one with rolling technique. Those samples were diagnosed with essential hypertension by the doctor. The result of this study found that the incidence of obesity was more in 51-60 group age. The highest frequency was loop pattern (50,2\%). The highest average total finger ridge count frequency was more than 20 (31\%). The number of triradius in the fingertips are normal and used as a point to count the ridges. This study showed the loop pattern as the highest frequency in essential hypertension patient, high average total ridge count, and normal number of triradius.

Keywords: essential hypertension, dermatoglyphics

Affiliasi penulis: 1. Prodi Profesi Dokter FK Unand (Fakultas Kedokteran Universitas Andalas Padang) 2. Bagian Ilmu Kedokteran Forensik FK Unand, 3. Bagian IImu Penyakit Dalam FK Unand. Korespondensi: Ando Amadino, Email:

ando_amadinos@yahoo.co.id, Telp: 081374202703

\section{PENDAHULUAN}

Hipertensi esensial atau juga dikenal dengan hipertensi primer adalah hipertensi yang tidak diketahui. ${ }^{1}$ Hipertensi dan komplikasinya adalah salah 
satu penyebab kematian nomor satu secara global. $^{2}$ Penderita hipertensi tahun 2003 adalah sekitar 600 juta orang di seluruh dunia. ${ }^{3} \mathrm{Di}$ Indonesia didapatkan penderita hipertensi adalah 25,8\%. ${ }^{4}$ Penderita hipertensi di Sumatera Barat sebesar 31,2\%. ${ }^{5}$

Hipertensi esensial adalah penyakit multifaktorial yang timbul karena interaksi dari faktorfaktor risiko tertentu, yaitu genetis, diet dan asupan garam, stress, ras, obesitas, dan merokok. ${ }^{1}$

Dermatoglifi berasal dari kata Yunani, Derma berarti kulit, glyphic berarti ukiran. ${ }^{6}$ Dermatoglifi adalah gambaran sulur-sulur dermal yang paralel pada jari-jari tangan dan kaki, serta telapak tangan, dan telapak kaki. $^{7}$ Dermatoglifi pada setiap orang tidak mungkin persis sama, tetapi bersifat sangat stabil dan tidak berubah sepanjang hidup kecuali bila terjadi kerusakan yang sangat parah sampai lapisan sub dermis. ${ }^{8}$ Gambaran sulur-sulur dermal ditentukan oleh banyak gen yang pengaruhnya saling menambah dan mungkin beberapa diantaranya bersifat dominan dan tidak dipengaruhi oleh faktor luar sesudah lahir, misalnya geografik, ekonomi dan lain-lain. ${ }^{7}$

Faktor genetik mempunyai peran penting dalam hipertensi esensial sedangkan bentuk pola sulur-sulur dermal ditentukan oleh banyak gen. Keadaan abnormal pada pertumbuhan sulur dermal masih tidak diketahui penyebabnya ${ }^{9}$, namun sangat mungkin disebabkan oleh gen-gen abnormal yang terdapat dalam berbagai kromosom, aberasi kromosom, dan bahkan karena efek obat-obatan pada masa dalam kandungan. ${ }^{10}$ Walaupun begitu, dermatoglifi tetap sangat membantu dalam memperkirakan diagnosis dari berbagai macam kelainan klinis, sehingga dengan menganalisa dermatoglifi pada jari-jari tangan akan berguna untuk deteksi dini kasus hipertensi esensial yang akan memudahkan untuk mencegah timbulnya efek dari penyakit ini dengan cara memodifikasi faktor risiko. Peran ilmu dermatoglifi bukanlah untuk mendiagnosa penyakit, tetapi berguna untuk memprediksi sebuah penyakit sehingga memudahkan untuk mengidentifikasi seseorang yang mempunyai faktor predisposisi genetik untuk penyakit tertentu. ${ }^{6}$

Penelitian yang dilakukan di India, menemukan rendahnya jumlah total sulur pada ujung jari, peningkatan pola arch, dan penurunan pola loop pada jari telunjuk kanan pasien pria pada kelompok hipertensi esensial dibandingkan kelompok tidak hipertensi esensial. ${ }^{11}$ Penelitian kedua, yang dilakukan oleh Lahiri (2013) menemukan, pola whorl dan arch adalah $4,57 \%$ dan $5,79 \%$ pada kelompok hipertensi esensial, dibandingkan dengan kelompok tidak hipertensi esensial yang hanya $0,44 \%$ dan $1,33 \%{ }^{12}$

\section{METODE}

Penelitian deskriptif ini dilakukan di Puskesmas Padang Pasir Kota Padang dan Puskesmas Ambacang Kuranji Kota Padang sejak bulan Januari 2014 sampai Juni 2014 dengan menggunakan 100 penderita hipertensi esensial. Penelitian dilakukan dengan menggunakan teknik simple random sampling.

\section{HASIL}

Subyek merupakan penderita hipertemsi esensial yang ada di Puskesmas Padang Pasir dan Puskesmas Ambacang Kuranji yang memenuhi syarat inklusi. Berdasarkan penelitian tersebut didapatkan karakteristik berupa jenis kelamin, umur, pola dermatoglifi.

Tabel 1. Distribusi subyek berdasarkan Jenis Kelamin

\begin{tabular}{ccc}
\hline Jenis Kelamin & $\mathbf{f}$ & $\%$ \\
\hline Perempuan & 66 & 66 \\
Laki-laki & 34 & 34 \\
Total & 100 & 100 \\
\hline
\end{tabular}

Berdasarkan Tabel 1 dapat dilihat bahwa subyek perempuan (66\%) lebih banyak dibandingkan laki-laki (34\%).

Tabel 2. Distribusi subyek berdasarkan Usia

\begin{tabular}{ccc}
\hline Umur & $\mathbf{f}$ & $\mathbf{\%}$ \\
\hline $21-30$ & 1 & 1 \\
$31-40$ & 7 & 7 \\
$41-50$ & 22 & 22 \\
$51-60$ & 28 & 28 \\
$61-70$ & 21 & 21 \\
$71-80$ & 19 & 19 \\
$81-90$ & 2 & 2 \\
\hline Jumlah & 100 & 100 \\
\hline
\end{tabular}


Berdasarkan Tabel 2 dapat dilihat bahwa kelompok umur responden dengan frekuensi hipertensi esensial tertinggi berusia 51-60 tahun yang mencapai 28 orang, ditemukan satu pasien hipertensi esensial pada kelompok umur termuda yang berusia 21-30 tahun dan didapatkan dua orang pasien hipertensi esensial pada kelompok umur tertua 81-90 tahun.

Tabel 3. Gambaran pola dermatoglifi penderita hipertensi

\begin{tabular}{lcc}
\hline \multicolumn{1}{c}{ Pola Sidik Jari } & $\mathbf{f}$ & $\boldsymbol{\%}$ \\
\hline Loop & 502 & 50,2 \\
Whorl & 404 & 40,4 \\
Arch & 94 & 9,4 \\
\hline Total & 1000 & 100 \\
\hline
\end{tabular}

Berdasarkan Tabel 3 dapat dilihat Persentase pola yang terbanyak adalah pola loop $(50,2 \%)$, diikuti pola whorl $(40,4 \%)$, dan pola arch $(9,4 \%)$.

Tabel 4. Jumlah total sulur sidik jari tangan penderita penyakit hipertensi esensial di Puskesmas Padang Pasir dan Puskesmas Ambacang Kuranji

\begin{tabular}{ccc}
\hline Jumlah Total Sulur (Rata-rata) & $\mathbf{f}$ & $\%$ \\
\hline Kurang dari 5 & 4 & 4 \\
$5-10$ & 19 & 19 \\
$10-15$ & 20 & 20 \\
$16-20$ & 26 & 26 \\
Lebih dari 20 & 31 & 31 \\
\hline Total & 100 & 100 \\
\hline
\end{tabular}

Berdasarkan Tabel 4 dapat dilihat peningkatan jumlah total sulur sidik jari tangan rata-rata penderita penyakit hipertensi esensial terdapat di kedua puskesmas, dimulai dari yang terendah yaitu kurang dari 5 yang berjumlah 4 orang, meningkat jumlahnya pada kelompok 5 - 10 sulur rata-rata yang berjumlah 19 orang. Sebanyak 20 orang memiliki jumlah sulur rata-rata 10 - 15 sulur. 26 responden yang diteliti memiliki jumlah total sulur rata-rata sebanyak 16-20 sulur dan jumlah total sulur rata-rata lebih dari 20 sulur terdapat pada 31 responden.
Tabel 5. Jumlah triradius pada ujung jari tangan penderita penyakit hipertensi esensial

\begin{tabular}{cccc}
\hline $\begin{array}{c}\text { Gambaran } \\
\text { Pola Dasar }\end{array}$ & $\mathbf{f}$ & $\begin{array}{c}\text { Jumlah } \\
\text { Total } \\
\text { Triradius }\end{array}$ & $\begin{array}{c}\text { Jumlah } \\
\text { Triradius } \\
\text { didapat pada } \\
\text { Setiap Pola }\end{array}$ \\
\hline Loop & 502 & 502 & 1 \\
Whorl & 404 & 808 & 2 \\
Arch & 63 & 0 & 0 \\
Tented Arch & 31 & 31 & 1 \\
\hline
\end{tabular}

Berdasarkan Tabel 5 dapat diketahui bahwa jumlah triradius yang didapatkan pada pola loop berjumlah 502 triradius dengan triradius pada setiap pola berjumlah 1 triradius, pada pola whorl berjumlah 808 triradius dengan rincian didapat 2 triradius pada setiap pola. Dalam penyajian ini, pola dasar arch dipisah menjadi dua bagian yaitu pola arch yang tidak memiliki triradius dan pola tented arch yang memiliki satu triradius.

\section{PEMBAHASAN}

Penelitian ini menemukan bahwa pola sidik jari dasar yang frekuensinya paling tinggi adalah pola loop yang jumlahnya mencapai $502(50,2 \%)$ dari total 1000 jari yang dimiliki oleh seluruh responden, diikuti oleh pola dasar whorl $(40,4 \%)$ dan frekuensi munculan pola sidik jari paling sedikit dihasilkan adalah pola dasar $\operatorname{arch}(9,4 \%)$ dari seluruh responden. Hasil penelitian ini mirip dengan hasil dari penelitian yang dilaksanakan oleh Lahiri (2013) yang mendapatkan temuan bahwa pola yang tersering ditemukan adalah pola dasar loop $(52,05 \%)$.Untuk pola dasar whorl didapatkan sebayak $(38,63 \%)$ dan pola arch ditemukan sebanyak $(5,79 \%)$. Penelitian ini secara statistik hasilnya signifikan dengan chi square value $(12,09)$ dan $p=0,016{ }^{12}$

Pada penelitian ini didapatkan data mengenai jumlah triradius pada ujung jari tangan penderita hipertensi esensial, yaitu satu triradius pada setiap pola loop sehingga pada pola ini didapatkan 502 triradius, dua triradius pada setiap pola whorl sehinga pada pola ini didapatkan 808 triradius, satu triradius pada setiap pola tented arch sehingga pada pola ini 
didapatkan 31 triradius dan tidak ditemukan triradius pada setiap pola arch.

Setiap pola yang ditemukan selalu memiliki titik triradius sesuai dengan jumlah normalnya. Pola plain arch tidak memiliki triradius, pola tented arch memiliki 1 triradius, pola loop memiliki 1 triradius, dan pola whorl memiliki 2 triradius. $^{13}$ Penelitian tentang jumlah triradius pada ujung jari tangan manusia dan keterkaitanya dengan hipertensi esensial tidak ditemukan, sehingga dalam penelitian ini triradius berfungsi sebagai patokan dalam menghitung total sulur jari dan menentukan nama pola sidik jari.

\section{SIMPULAN}

Gambaran tipe pola sidik jari tangan penderita hipertensi esensial di Puskesmas Padang Pasir dan Puskesmas Ambacang Kuranji terbanyak adalah pola Ioop, diikuti pola whorl, dan yang paling sedikit adalah pola arch.

Jumlah triradius jari tangan penderita hipertensi esensial di Puskesmas Padang Pasir dan Puskesmas Ambacang Kuranji ditentukan oleh pola dasar sidik jari tangan pada pasien tersebut.

Jumlah total sulur jari tangan penderita hipertensi esensial di Puskesmas Padang Pasir dan Puskesmas Ambacang Kuranji terbanyak, rata-rata berjumlah lebih dari 20 sulur dan paling sedikit berjumlah rata-rata kurang dari 5 sulur.

\section{DAFTAR PUSTAKA}

1. Yogiantoro M. Dalam: Sudoyo AW, Setiyohadi B, Alwi I, Simadibrata M, Setiati $S$, editor (penyunting). Buku ajar ilmu penyakit dalam. Jakarta: Pusat Penerbitan Departemen IImu Penyakit Dalam FKUI; 2009

2. JNC VII. The seventh report of the joint national committee on prevention, detection, evaluation, and treatment of high blood pressure. hypertension. 2003;42:1206-52.

3. WHO-ISH Hypertension guideline committee. Guidelines of the management of hypertension. J Hypertension. 2003;21(11):1983-92.

4. Badan Penelitian dan Pengembangan Kesehatan. Riset kesehatan dasar 2013. Jakarta: Kementrian Kesehatan RI; 2013.hlm.83-4.

5. Badan Penelitian dan Pengembangan Kesehatan. Riset kesehatan dasar 2007. Jakarta: Kementrian Kesehatan RI; 2007.hlm.46.

6. Rudragouda S, Bulagouda. Study of palmar dermatoglyphics in pasien essential hypertension between the age group of 20-50 years. Int $\mathrm{J}$ Med Res Health Sci. 2013;2(4):773-9.

7. Rosida L, Panghiyangani R. Gambaran dermatoglifi pada sindroma Down di Banjarmasin dan Martapura Kalimantan Selatan. Jurnal Anatomi Indonesia. 2006;1(2):71-8.

8. Siburian J. Analisis pola sidik jari tangan dan jumlah sulur serta besar sudut ATD penderita diabetes melitus di rumah sakit umum daerah Jambi. Biospecies. 2010;2(2):12-7.

9. Hoover J. The science of fingerprints: classification and uses. 2006.hlm.52-3.

10. Kaur J, Batra A. Role of dermatoglyphics in medical disorders. Indian Journal of Fundamental and Applied Life Sciences. 2013;3(3):536.

11. Deepa. G. Study Of palmar dermatoglyphics in essential hypertension. NJIRM. 2013;4(3):61-5.

12. Lahiri A. A study on relationship between dermatoglyphics and hypertension. Journal of Dental and Medical Sciences. 2013;7(6):62-5.

13. Ramani P, Abhilash, Sherlin H, Anuja. Conventional dermatoglyphics-revive concept: a review. International of Pharma and Bio Science. 2011;2(3):446-58. 